\title{
Some Aberrant Specimens of Puntius sarana sarana (Ham.-Buch.) from Fresh-Water Bodies of Jammu District of Union Territory of Jammu and Kashmir (India)
}

\author{
Dutta SPS* \\ Department of Environmental Sciences, University of Jammu, Jammu (180006), India \\ *Corresponding author: Dr. Dutta SPS, Department of Environmental Sciences, University of Jammu, Jammu (180006), India; Email: duttasps@gmail.com
}

Received: December 28, 2021; Accepted: January 03, 2022; Published: January 05, 2022

\begin{abstract}
Six deformed specimens of Puntius sarana sarana (Ham.-Buch.) were observed, over a period of ten years, among fish collections by fishermen from Pargwal wetland, Akhnoor, and Ranbir Singh Pura area (R.S. Pura) of Jammu district and have been elaborated. Deformities observed include dorsal fin injury and naked eye count of six dorsal fin rays (4/2) in one specimen, slightly truncated one specimen and highly truncated and much shortened body along antero-posterior axis (stumpbody) and fins displacement in four specimens. $X$ ray analysis has revealed six well developed and five rudimentary skin embedded fin rays and dorsal fin injury in one specimen and antero posterior irregular compressed vertebrae in five specimens. Dorsal fin deformity in one specimen is caused by a biological predator and Myxobolus infection. A possible cause of deformities in other five fish specimens is pesticides and herbicides spray in agricultural fields causing water contamination.
\end{abstract}

Keywords: Puntius sarana sarana, Deformities, Truncated and stumpbody, Vertebral compression, Myxobolus sp, Pesticides and herbicides

\section{Introduction}

Puntius sarana sarana, among seven Puntius spp. distributed in Jammu waters [1], is on record in Kathua [2-6], Samba [7,8], Jammu $[9,10]$ and Udhampur [11] districts of Jammu region. This important food fish attains a maximum weight of $1 \mathrm{~kg}$. Anomalies among genus Puntius are rare and have earlier been reported [12,13]. Deformities in other wild fish populations in Jammu waters, due to good water quality and absence of pollution, are rare and have earlier been described [1429] over a study period of about forty years. During the fish survey of lotic and lentic water bodies of R.S. Pura and Pargwal wetland, for a period of about ten years, six deformed specimens of Puntius sarana sarana were noticed among fish collections by fishermen and have been described. Skeletal deformities can influence morphology and growth and can hinder the movement of fishes and, thus, they become less capable to find food and avoid predators. Knowledge of fish deformities is important for a taxonomist, as lack of any proper knowledge of fish aberrations can sometimes lead to wrong fish identification and creation of new species. Deformities occurrences in fish seems to be a good and practical way of assessing environmental quality [30-33], pollution [34-40] and environmental stress [35,4143].

\section{Topography and Material and Method}

Pargwal wetland in Akhnoor is formed by the river Chenab, an important Himalayan river draining Jammu region, before entering plains in Pakistan. Water flow of the river Chenab in the area is suddenly reduced and there is wide spread of agricultural fields. Spring fed lotic water bodies, having quality water, are widely distributed in the Pargwal wetland and support a rich fish diversity. Ranbir Singh Pura area is plain and has a large number of freshwater streams, ponds and irrigation canals. The area is famous for quality paddy production. Deformed specimens of Puntius sarana sarnna were seen over a period of ten years among fish collections by fishermen, purchased, photographed and radiographed by digital $\mathrm{X}$ ray machine (AGFA).

\section{Observations}

Six deformed specimens of Puntius saranasarana were observed during the present fish survey and are described below:

\section{Dorsal Fin Deformity in Puntius sarana sarana}

This deformed specimen of Puntius sarana sarana, measuring 27 $\mathrm{cm}$ and weighing $260 \mathrm{~g}$, was seen among fish collections from RS Pura area. It was recognised by injured dorsal fin area and decreased size of anterior and absence of posterior fin rays (Figures 1-3). Study of dorsal fin has revealed the presence of six dorsal fin rays (4/2) against thirteen (4/9) in a normal fish. Microscopic study of injured skin has shown the presence of Myxobolus spores in large number.

$\mathrm{X}$ ray study of dorsal fin of deformed fish specimen has shown the presence of eleven fin rays, six well developed visible outside the body and five degenerated (Figure 4). 


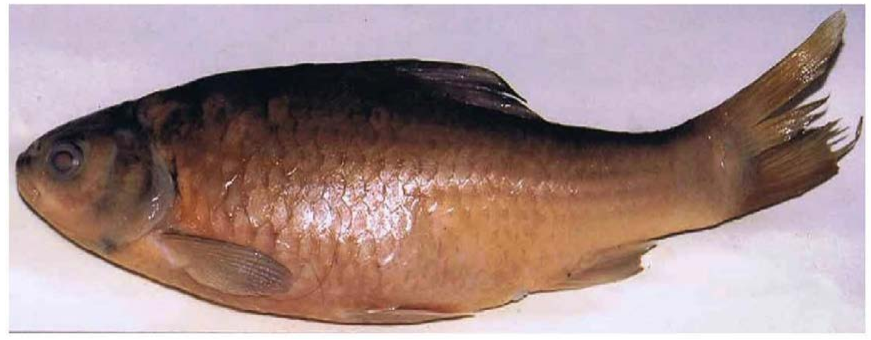

Figure 1: Photograph of normal Puntius sarana sarana (Ham.-Buch.)

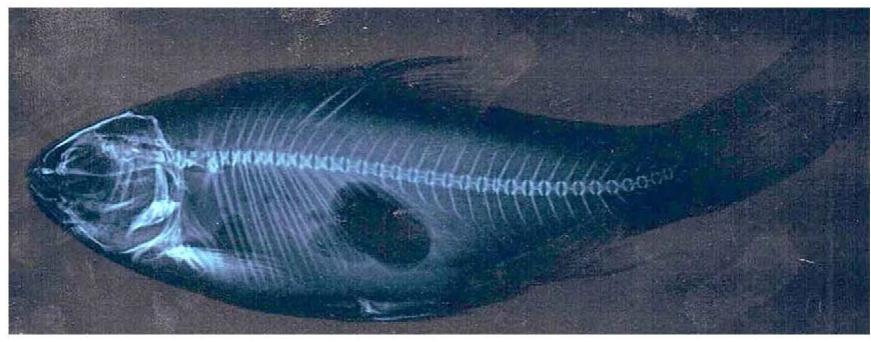

Figure 2: X-Ray photograph of normal Puntius sarana sarana (Ham.-Buch.)

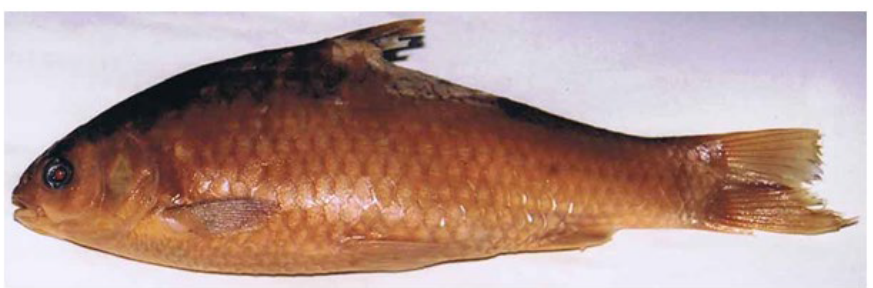

Figure 3: Photograph of Puntius sarana sarana (Ham.-Buch.) with dorsal fin deformity.

\section{Puntius sarana sarana with Slightly Truncated Body, Including Caudal Peduncle, and Dorsal Fin Displacement}

This deformed specimen of Puntius sarana sarana, measuring 18 $\mathrm{cm}$ and weighing $140 \mathrm{~g}$, was seen among fish collections from RS Pura area. It was recognised by truncated body and displacement of dorsal fin. In a normal fish dorsal fin installation is towards the snout tip than the caudal fin base. In this deformed fish dorsal fin is located towards caudal fin base. Caudal peduncle of this deformed fish is slightly truncated and there is reduction in space between longest anal fin ray and caudal fin base.

$\mathrm{X}$ ray analysis has shown the presence of 32 biconcave vertebrae and a urostyle in a normal and abnormal fish (Figures 2 and 6).

In this deformed fish first 12 vertebrae are thin and closely placed with normal centra.In the posterior vertebrae, vertebral thickness and centra are reduced and anterior side is concave and posterior side flat, thereby, showing a loss of normal biconcave shape of vertebrae seen in a normal fish (Figures 2 and 6).

\section{Stump and Highly Truncated Body with Displacement of Fins}

Four deformed fish specimens of Puntius sarana sarana with much deep body shortened along antero-posterior axis (stumpy body) with much shortened trunk compared to a normal fish were seen in Jammu and are described below:

This deformed specimen of Puntius sarana sarana, measuring 19.5 $\mathrm{cm}$ and weighing $240 \mathrm{~g}$, was seen among fish collections from R S Pura area. Contrary to 3.5 body depth in total body length in a normal fish, in this deformed fish specimen body depth in total body length is 2.16. Dorsal fin installation is towards caudal fin base than the snout tip and longest anal fin ray extends caudal fin base. Contrary to this in a normal fish dorsal fin installation is towards snout tip and there is wide space between longest anal fin ray and caudal fin base. There is a semicircular abdominal protuberance between pelvic and anal fin base. Postdorsally body scales in this deformed fish are short, unequal and overlap. Lateral line short due to truncated body (Figures 7).

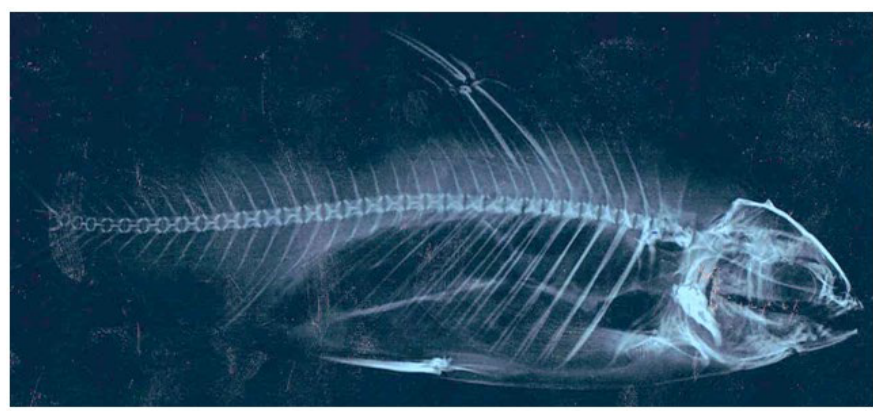

Figure 4: X-ray photograph of Puntius sarana sarana (Ham.-Buch.) with dorsal fin deformity.

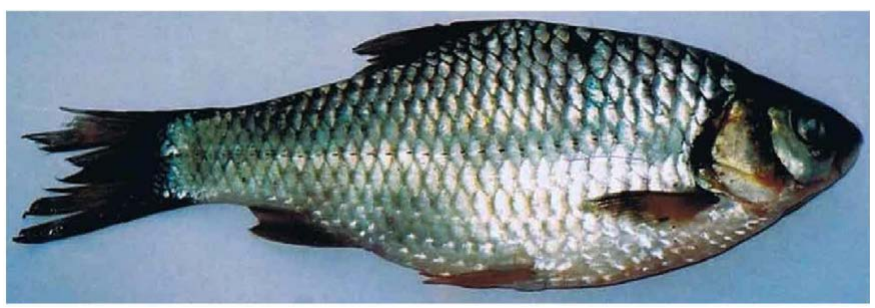

Figure 5: Photograph of Puntius sarana sarana (Ham.-Buch.) showing moderate truncated body.

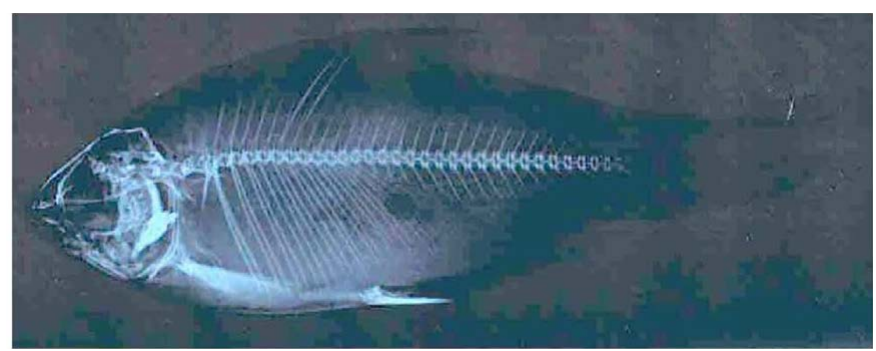

Figure 6: X Ray photograph of Puntius sarana sarana (Ham.-Buch.) showing moderate truncated body.

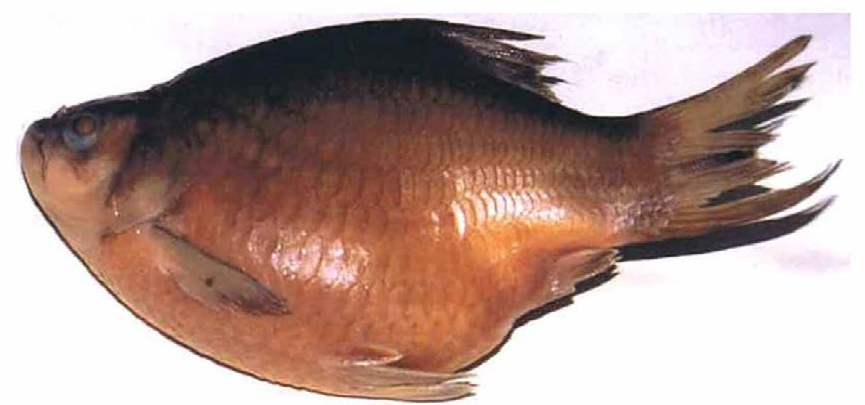

Figure 7: Photograph of Puntius sarana sarana (Ham.-Buch.) showing stump and highly truncated body. 
Dutta SPS (2022) Some Aberrant Specimens of Puntius sarana sarana (Ham.-Buch.) from Fresh-Water Bodies of Jammu District of Union Territory of Jammu and Kashmir (India)

In a normal and abnormal fish there are 32 biconcave vertebrae and a urostyle (Figures 2 and 8).Vertebral column in deformed fish is antero-posteriorly is irregularly compressed irregularly and is described as under:

i) $1^{\text {st }}$ opaque vertebra fused with complex vertebral complex.

ii) $\quad 2^{\text {nd }}$ vertebra highly compressed and opaque.

iii) $3^{\text {rd }}-12^{\text {th }}$ vertebrae, with reduced inter-verterbral spaces, are slightly compressed.

iv) $14^{\text {th }}$ to $15^{\text {th }}$ vertebrae compressed and centra reduced.

v) $16^{\text {th }}$ vertebra normal.

vi) $17^{\text {th }}$ to $25^{\text {th }}$ vertebrae highly compressed with reduced centra.

vii) $26^{\text {th }}$ to $28^{\text {th }}$ vertebrae normal.

viii) $29^{\text {th }}$ to $32^{\text {nd }}$ vertebrae highly truncated, vertebral centra and intervertebral spaces not clear.

This stump and truncated fish, measuring $20 \mathrm{~cm}$ and weighing 220 $\mathrm{g}$, was seen in collections from Pargwal wetland area. Its height in total body length is 2.5 . In a normal fish dorsal fin installation is towards the snout than the caudal fin base. Whereas, dorsal fin installation in this abnormal fish is more towards caudal fin base than the snout tip. Longest anal fin ray extends caudal fin base. There is a semicircular abdominal protuberance between pelvic and anal fin base. Post dorsally body in this aberrant fish is covered by short overlapping scales and lateral line is truncated (Figure 9).

$\mathrm{X}$ ray analysis has shown 32 biconcave vertebrae and urostyle in both normal and abnormal fish (Figures 2 and 12). In this stump and truncated fish vertebrae are variably compressed and are discussed as

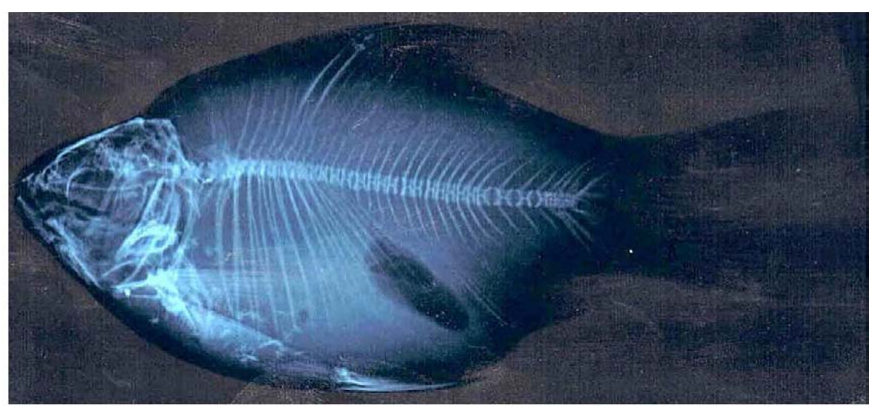

Figure 8: Photograph of Puntius sarana sarana (Ham.-Buch.) showing stump and highly truncated body.

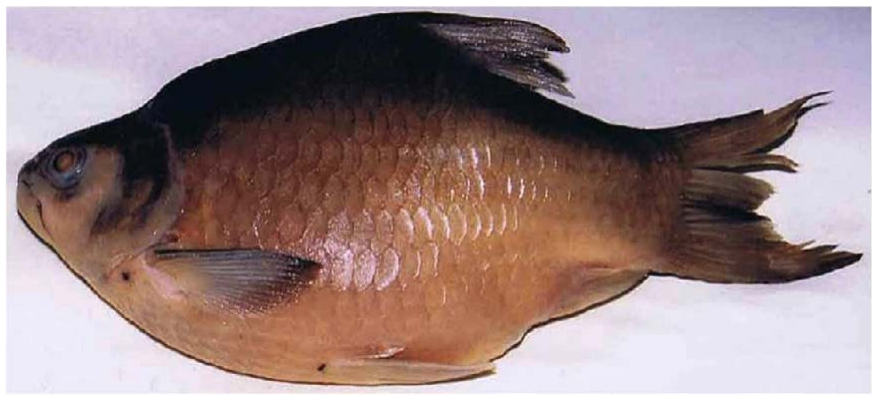

Figure 9: Photograph of Puntius sarana sarana (Ham.-Buch.) showing stump and highly truncated body. below".

i) $\quad 1^{\text {st }}$ vertebra is fused with complex vertebral mass.

ii) $\quad 2^{\text {nd }}$ to $6^{\text {th }}$ vertebrae highly compressed, attenuated and opaque and vertebral thickness reduced.

iii) $7^{\text {th }}-10^{\text {th }}$ vertebrae have reduced vertebral thickness and intervertebral spaces.

iv) $11^{\text {th }}-27^{\text {th }}$ vertebrae compressed antero-posteriorly with anterior side concave and prosterior flat, thereby, losing normal biconcave vertebral shape. Centra, vertebral thickness and intervertebral spaces reduced.

v) $28^{\text {th }}$ vertebrae normal.

vi) $\quad 29^{\text {th }}-30^{\text {th }}$ vertebrae have slightly reduce vertebral thickness.

vii) $\quad 31^{\text {st }}-32^{\text {nd }}$ vertebrae highly compressed with rudimentary centra.

viii) Urostyle and caudal bones normal.

This aberrant fish specimen, measuring $19.2 \mathrm{~cm}$ and weighing 260 $\mathrm{g}$, was seen in collections from Pargwal wetland area. Its body height in total body length is 2.2. Contrary to this in a normal fish body height in total body length is 3.5.Dorsal fin installation is towards caudal fin base than the snout tip and longest anal fin ray almost extends caudal fin base. Whereas in a normal fish dorsal fish installation is towards snout tip and there is a long gap between longest anal fin ray and caudal fin base. There is an abdominal protuberance between pelvic and anal fin base. Postdorsally body scales are short and overlap (Figure 11).

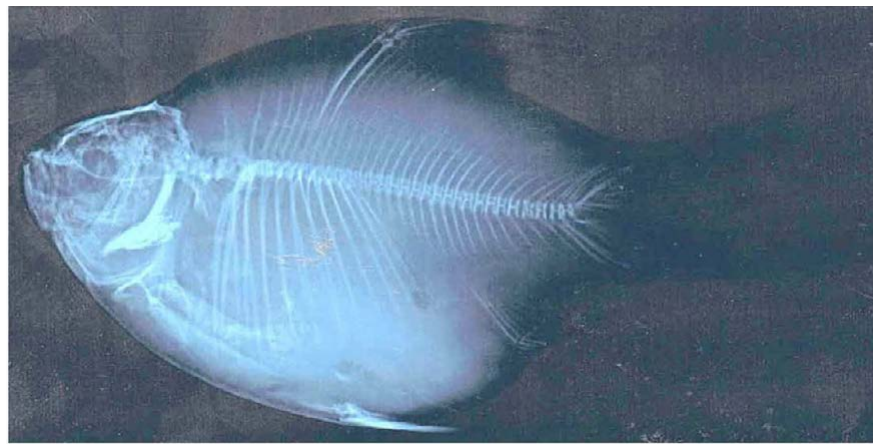

Figure 10: $\mathrm{X}$ ray photograph of Puntius sarana sarana (Ham.-Buch.) showing stump and highly truncated body.

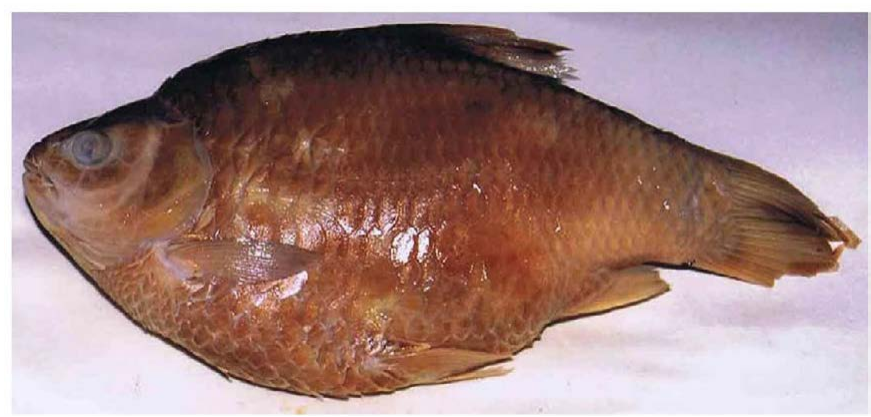

Figure 11: Photograph of Puntius sarana sarana (Ham.-Buch.) showing stump and highly truncated body. 


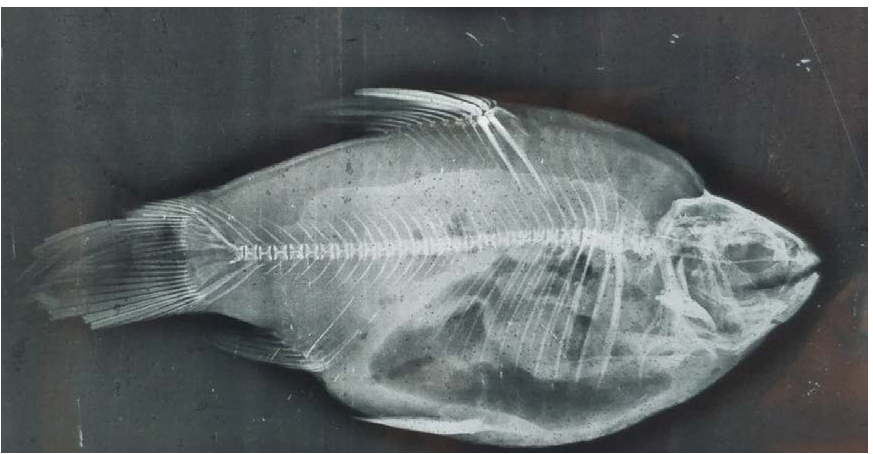

Figure 12: X ray photograph of Puntius sarana sarana (Ham.-Buch.) showing stump and highly truncated body.

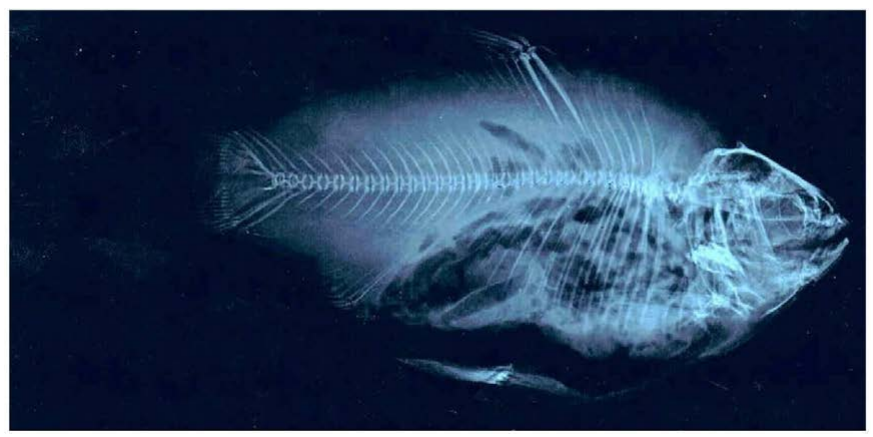

Figure 13: X ray photograph of Puntius sarana sarana (Ham.-Buch.) showing stump and highly truncated body.

$\mathrm{X}$ ray analysis has shown thirty-two biconcave vertebrae in normal and 31 vertebrae and urostyle in abnormal fish (Figures 2 and 10). There is variable antero posteriorly vertebral compression in this aberrant fish and is described as below:

i) First four vertebrae compressed and form an opaque fused mass (ankylosis).

ii) $5^{\text {th }}-14^{\text {th }}$ vertebrae, except $4^{\text {th }}$ and $10^{\text {th }}$ compressed verterbrae, are almost normal.

iii) $15^{\text {th }}-17^{\text {th }}$ vertebrae highly compressed and opaque.

iv) $18^{\text {th }}-25^{\text {th }}$ vertebrae slightly compressed with reduced vertebral thickness and intervertebral spaces.

v) $26^{\text {th }}-31^{\text {st }}$ vertebrae almost normal.

This deformed specimen of fish measuring $20 \mathrm{~cm}$ and weighing $280 \mathrm{~g}$, was purchased from a fisherman in Pargwal wetland area. Body height in total length is 1.5 in this abnormal fish specimen. On the contrary in a normal fish body height in total length is 3.5. In a normal fish there is a wide space between longest anal fin ray and caudal fin base. Whereas, in the abnormal fish longest anal fin ray almost extends caudal fin base. There is an abdominal protuberance between pelvic and anal fin base. Body scales are highly reduced in post dorsal region.

$\mathrm{X}$-ray analysis has shown the presence of 32 biconcave vertebrae and urostyle in both normal and abnormal fish (Figures 2 and 13). Vertebrae in this abnormal fish specimen are highly compressed antero-posteriorly and are described as under.

1. First five vertebrae highly compressed attenuated, opaque with reduced centra and intervertebral spaces.
2. $6^{\text {th }}$ to $14^{\text {th }}$ vertebrae irregularly compressed.

3 . $15^{\text {th }}$ to $16^{\text {th }}$ vertebrae highly compressed and attenuated with opaque centra.

4. Posteriorly, $16^{\text {th }}$ to $27^{\text {th }}$ vertebrae show a gradual increase in vertebral thickness and intervertebral spaces.

5. $28^{\text {th }}$ to $32^{\text {nd }}$ vertebrae and urostyle normal.

In all the above described four stumpbody fishes (Figures 8, 10, 12 and 13) with variable compressed trunk and caudal vertebrae, some pleural ribs are double and some irregularly fused. Whereas, in a normal fish. There are double pleural libs on trunk vertebrae (Figures 2 and 4).

\section{Discussion}

Collection of only six deformed fish specimens of Puntius sarana sarana in Jammu district, over a period of ten years, suggests a rare occurrence of such fishes in Jammu waters. This is because they are less abundant or because of the decreased viability of abnormal fishes in their natural habitat as they easily fall prey to the predators. This poor record of deformed fishes is also due to good water quality of water bodies in the area of sampling and absence of industrial pollution [3440]. Record of these adult fishes suggests that deformities are not fatal and these are able to avoid predators and feed normally.

Vertebral anomalies commonly reported among fishes are lordosis, kyphosis, scoliosis, ankylosis, coiling, duplication, compression etc. Among the presently described fishes one specimen of Puntius sarana sarana sampled from RS Pura area has shown dorsal fin deformity, with five rudimentary and six well developed fin rays and presence of Myxobolus spores in the skin. This dorsal fin rays deformity is caused by Myxobolus infection and is in accordance to the earlier observations [16]. Shortening of dorsal fin rays and wound can also be due to some biological predators.

Five specimens of Puntius sarana sarana have shown anteroposterior variable degree of vertebral compression and there is absence of any spinal curvature. Absence of any severe vertebral anomalies (spinal curvature) in wild caught fishes have also been reported by earlier workers $[13,19,31,44]$. Vertebral compression in Tor tor and Tor putitora from the river Chenab, Akhnoor, Jammu, has been attributed to fast currents in their breeding grounds, along the river Chenab [19]. Vertebral column compression among the five specimens of Puntius sarana sarana, under discussion, cannot be attributed to currents as these fishes have been sampled from sluggish water bodies in plain areas of R S Pura and Pargwal wetland.

Absence of any industry in the area of present fish study suggests that aberrations, under discussion, are not due to industrial and sewage water pollution, as deformed fishes are abundant in polluted waters [17,34-40].

Common use of pesticides and herbicides in widespread agricultural fields in R.S. Pura and Pargwal wetland causing water contamination may be an important factor inducing morphological and vertebral aberrations during developmental stages and have earlier been reported [45-50]. 
Dutta SPS (2022) Some Aberrant Specimens of Puntius sarana sarana (Ham.-Buch.) from Fresh-Water Bodies of Jammu District of Union Territory of Jammu and Kashmir (India)

More research on water quality, heavy metals and pesticides is required to identify the factors causing stumpbody and vertebral compressions.

\section{References}

1. Dutta SPS (2017) Survey and systematic analysis of fish fauna of Jammu region with reference to coldwater fish. Prof Emeritus Project Report submitted to the UGC, New Delhi.

2. Dutta SPS, Kaur H (2005) Fish fauna of Kathua district, Jammu region, J\&K State. In: Proceedings National Seminar "New Trends in Fishery Development in India", Panjab University, Chandigarh. February 16-18: 233-240.

3. Rathore V, Dutta SPS (2015) Fish fauna of river Ujh, an important tributary of the river Ravi, District Kathua, Jammu. Environment Conservation J 16: 81-86.

4. Dutta SPS (2016) Fish fauna of Wajoo nullah, an important tributary of river Ravi, in Kathua District, Jammu region, Jammu and Kashmir State, India. JANS 8: 1087-1089.

5. Dutta SPS (2021) Fish fauna of the river Ravi and its some tributaries with a new record of Ailia punctata and Clupisoma naziri for Punjab state and Union territory of Jammu and Kashmir, India. Aquaculture and Fisheries Studies 3: 1-5.

6. Guglani HK (2000) Survey and systematic analysis of fish fauna of Jammu region. Ph.D. Thesis, University of Jammu, Jammu.

7. Dutta SPS, Kour H, Bali JPS, Sharma ID (2001) Hydrobiological studies of river Basantar. Samba, J Aquatic Biol 16: 41-44.

8. Sharma A, Dutta SPS (2012) Present and past status of fish fauna of river Basantar, an important tributary of the river Ravi in Samba district, Jammu (J\&K). J Applied and Natural Resources 4: 123-126.

9. Dutta SPS, Kour H (2005) Icthyofauna of Jammu district of Jammu region, J\&K State. In: Fisheries and Aquaculture in Indus River region. Editor M.P. Singh Kohli: 87-99.

10. Dutta SPS (2012) Limnology of the river Chenab, at Kahnoor, Jammu Part 1 Water quality, zooplankton and fish. Project Report submitted to the UGC. Bahadur Shah Zafar Marg, New Delhi.

11. Dutta SPS (2015) Survey and systematic analysis of fish fauna of erstwhile Udhampur district, Jammu region, with new records of Barilius radiolatus Gunther, Botia lohachata Chaudhary, Botia dario (Ham.-Buch.) and Glyptothorax punjabensis Mirza and Kashmiri Environment Conservation Journal 16: 39-47.

12. Dutta SPS, Kumar S (1991) Deformity in dorsal fin in Puntius conchonius (Ham) from Jammu. Geobios new Reports 10: 169-170.

13. Gupta SC, Dutta SPS, Verma M (1998). A report on abnormal specimen of Puntius sarana (Ham.) from river Basantar, Samba, Jammu (J\&K). J Freshwater Biol 10: 137140 .

14. Dutta SPS (1989-1990) Vertebral-spinal deformity in Barilius vagra (Ham) from Jammu Matsya 15-16: 166-168.

15. Dutta SPS (2016a) Some deformed specimens of Mystus bleekeri (Day) and Labeo bata (Ham. - Buch.) from the river Chenab in Pargwal wetland, Akhnoor, Jammu. Journal of Applied and Natural Science 8: 481-484.

16. Dutta SPS (2016b) Record of an abnormal Schizothoraichthys esocinus (Heckel) from the Himalayan river Chenab draining Jammu region of the J \& K state, India. Journal of Aquaculture Research and Development 7: 2-4.

17. Dutta SPS (2018) Record of some deformed specimens of Cirrhinus mrigala (Ham.Buch) from river Tawi in Jammu city. The Bioscan 13: 831-834.

18. Dutta SPS (2021) Rudimentary caudal peduncle in Bagarius bagarius (Ham.-Buch) and blunt head, rudimentary snout and abnormal mouth in Labeo dero (Ham.-Buch) from river Tawi, Jammu, J\&K UT, India. Examines Marine Biology Oceanography 4 (2): $1-4$.

19. Dutta SPS, Farooq S (2021) Some deformed specimens of Tor tor (Ham.-Buch.) and Tor putitora (Ham.-Buch.) from the torrential river Chenab, an important Himalayan river, draining Union territory of Jammu and Kashmir, India. Aquaculture and Fisheries Studies 3: 1-5.

20. Dutta SPS, Malhotra YR (1986) Absence of pelvic fins in Ompok bimaculatus (Bloch) Geobios. new Reports 5: 73-74.

21. Dutta SPS, Sheikh H (2017) Skeletal deformities in Bagarius bagarius (Ham.-Buch) and Crossocheilus latius dilocheilus (Ham.-Buch) from river Tawi, a Himalayan stream, in Udhampur area, Jammu region, J\&K, India. International Journal of Fisheries and Aquatic Studies 5: 247-251.

22. Dutta SPS, Kour H, Koul V (1995) Deformity in dorsal fin in Trichogaster fasciatus obtained from river Tawi, Jammu Him J Env Zool 9: 25-26.

23. Dutta SPS, Kour H, Sharma J (1996) Occurrence of malformed specimen of Labeo bata (Hem.-Buch) in river Tawi, Jammu. J Nature Conservators 8: 147-149.

24. Dutta SPS, Malhotra YR, Sharma J, Sinha OP (1989) Deformities in some freshwater fishes of Jammu (J \&K). Proc nat Acad Sci 59: 451-453.

25. Dutta SPS, Sharma J, Koul V (1993) A truncated specimen of Garra lamta (Ham.) J NATCON 5: 115-116.

26. Dutta SPS, Kour H (1994) Pelvic fins deformity in Schizothorax richardsonii (Gray and Hard) inhabiting Rajouri river. J Freshwater Biol 6: 195-196.

27. Malhotra YR, Dutta SPS (1986-87) Absence of anal fin in Rasbora daniconius (Ham.Buch). Matsya 12 -13: 177-180.

28. Shekhar C, Dutta SPS (1993) An abnormal specimen of Schizothorax richardsonii (Gray and Hard) with vertebral deformity. Him J Zool 7: 101-102.

29. Kour H, Kaul V, Dutta SPS (1996) Deformities in some freshwater fishes of Jammu. J Freshwater Biol 18: 213-216.

30. Kirpichnikov VSL (1945) Viability, rate of growth and morphology of carps of different genotypes as affected by rearing conditions. Comp. Reud Acad Sci Moscow NS 47: 503-506. [crossref]

31. Gavaia PJ, Dinis MT, Cancela ML (2002) Oesteological development and abnormalities of the vertebral column and caudal skelton in larval and juvenile stages of hatchery-reared Senegal sole (Solea, senegalensis). Aquaculture 211: 305-323.

32. Sfakianankis DG, Georgakopoulou E, Papadakis I, Divanch P, Kentouri M, et al. (2006) Environmnetal determinants of haemal lordosis in a European sea bass, Dicentrachus labrux (Linneuas 1768). Aquaculture 254: 54-64.

33. Aydin I (2012) The external abnormalities of hatchery-reared Black sea flounder (Platichthys flesus luscus Pallas 1814) in Turkey. Turkish journal of Fisheries and Aquatic Sciences 12: 127-133.

34. Bengtsson BE (1979) Biologoical variables, especially skeletal deformities in fish, for monitoring marine pollution. Phil Trans Roy Soc Lond 286: 457-464. [crossref]

35. Bengtsson B E (1988) Effects of pulp mill effulents on skeletal parameters in fish - a progress report. Water Science and Technology 20: 87-94.

36. Bengtsson BE, Bengtsson A, Hinberg M (1985) Fish deformities and pollution in some Swedish waters. Ambio 14: 32-35.

37. Sloof W (1982) Skeletal anomalies in fish from polluted surface waters. Aquatic Toxicol 2: 157-173.

38. Weis J S, Weis P (1987) Pollutant as developmental toxicants in aquatic organisms. Environmental Health Perspectives 71: 77-85.

39. Sun P L, Hawkins W E, Overstreet R M, Brown-Peterson N J (2009) Morphological deformities as biomarkers in fish from contaminated rivers in Taiwan. Int J Environ Res Public Health 6: 2307-2331.

40. Jawad L A, Ibrahim M, Farooq M M S (2019) Severe scoliosis and fin deformities in three fish species collected from Jaubail vicinity, Saudi Arabia, Arbain gulf. Thalassas: An International Journal of Marine Sciences 35: 591-598.

41. Lemly AD (1993) Teratogenic effects of Selenium in natural populations of freshwater fish. Ecotoxicology and Environmental Safety 26(1): 181-204. [crossref]

42. Boglione C, Costa C, Gigranti M, Cecchetti M, Di Dato P, et al. (2006) Biological monitoring of wild thick lip grey mullet (Chelonlabrosus), golden grey mullet ( $L i z a$ aurata)thin lip mullet (Liza ramada) and fathead mugil (Mugelcephalus) (Pisces; Mugilidae from different Adriatic sites) Meristic counts and skeletal anomalies. Ecological Indicators 6: 712-732.

43. Koumoundouros G (2008) First record of saddle back syndrome in wild parrot fish (Sparisoma cretense L, 1758) (Perciformes, Scaridae). Journal of Fish Biology 72: 737741.

44. Boglione C, Gagliardi F, Scardi M, Cataudella S (2001) Skeltal descriptors and quality assessment in larvae and post-larvae of wild caught and hatchery reared gillhead sea bream (Sparus aurata L 1758). Aquaculture 192: 1-22. 
Dutta SPS (2022) Some Aberrant Specimens of Puntius sarana sarana (Ham.-Buch.) from Fresh-Water Bodies of Jammu District of Union Territory of Jammu and Kashmir (India)

45. Couch JA, Winstead JA, Goodman LR (1977) Kepone induced scoliosis and histological consequences in fishes. Science 197: 585-587. [crossref]

46. Lien NTH, Adriaens D, Lanssen CR (1997) Morphological abnormalities in African cat fish (Clarias gariepinus) larvae exposed to malathion. Chemosphere 35: 14751486. [crossref]

47. Middaugh DP, Fourni JW, Hemmer MJ (1990) Vertebral abnormalities in juviniles inland silver sides Menidia beryllina exposed to turbufos during embryogenesis. Diseases of Aquatic Organisms 9: 109-116.
48. Dulcic J (2004) Incidence of spinal deformaities in natural populations of grass goby, Zosterisessor ophiocephalus from the Karin sea, eastern middle Adriatic. Cybium 28: 7-11.

49. Mochida K, Ito R, Harino H, Ondaka T, Kauno A, et al. (2008) Early life stage toxicity test for copper pyrithione and induction of skeletal anomaly in Teleost, the mummichog (Fundulus heteroclitus). Environmental Toxicology and Chemistry 27: 367-374. [crossref]

50. Celik ES, Kaya H, Yilmaz S (2012) Effects of phosalone on mineral contents and spinal deformities in common carp (Cyprinus carpio L, 1758). Turkish Journal of Fisheries and Aquatic Sciences 12: 259-264.

\section{Citation:}

Dutta SPS (2022) Some Aberrant Specimens of Puntius sarana sarana (Ham.-Buch.) from Fresh-Water Bodies of Jammu District of Union Territory of Jammu and Kashmir (India). Aquac Fish Stud Volume 4(1): 1-6. 